\title{
The Relationship Between Occupational Health (K3) And Motivation With Employee Performance At PT. Sarana Bandar Nasional Surabaya
}

\author{
Afif Subarkah and Hermien Tridayanti \\ Program Studi Manajemen, Fakultas Ekonomi Dan Bisnis \\ Universitas Narotama, Surabaya \\ Email author: hermin.tridayanti@narotama.ac.id
}

\begin{abstract}
With the various demands regarding occupational health and safety issues, companies must be able to fulfill their responsibilities in protecting employees by carrying out occupational health and safety programs. It is only natural that the workforce also plays an active role and takes responsibility for the implementation of programs for the maintenance and improvement of welfare for the realization of good protection for workers and their families. So, not only the company is responsible for this problem, but employees must also take an active role in this to achieve common welfare. Based on the description above, the purpose of this study aims to determine the relationship between K3 and Motivation with Employee Performance at PT. Surabaya National Airport Facility. The population used in this study are employees of PT. Sarana Bandar Nasional Surabaya with samples taken were 40 respondents. The research model uses Spearman rank correlation to test the significance of the hypothesis. Based on data analysis and discussion of the research results that have been stated, it can be concluded that the following questions are answered: Occupational safety and health have a moderate relationship with employee performance. Motivation has a strong relationship with employee performance.
\end{abstract}

Keyword:

Occupational Health and Safety, Employee Motivation and Performance

\section{Pendahuluan}

Sumber daya manusia merupakan peranan yang penting bagi keberhasilan suatu organisasi atau perusahaan, karena manusia merupakan aset hidup yang perlu dipelihara dan dikembangkan. Oleh karena itu karyawan harus mendapatkan perhatian yang khusus dari perusahaan. Kenyataan bahwa manusia sebagai aset utama dalam organisasi atau perusahaan, harus mendapatkan perhatian serius dan dikelola dengan sebaik mungkin. Hal ini dimaksudkan agar sumber daya manusia yang dimiliki perusahaan mampu memberikan kontribusi yang optimal dalam upaya pencapaian tujuan organisasi. Dalam pengelolaan sumber daya manusia inilah diperlukan manajemen yang mampu mengelola sumber daya secara sistematis, terencana, dan efisien. Salah satu hal yang harus menjadi perhatian utama bagi manajer sumber daya manusia ialah sistem Keselamatan dan Kesehatan.

Kesehatan dan Keselamatan Kerja termasuk salah satu program pemeliharaan yang ada di perusahaan. Pelaksanaan program keselamatan dan kesehatan kerja bagi karyawan sangatlah penting karena bertujuan untuk menciptakan sistem keselamatan dan kesatuan kerja dengan melibatkan unsur manajemen, tenaga kerja, kondisi dan lingkungan kerja yang terintegrasi dalam rangka mengurangi kecelakaan.

Masalah perlindungan tenaga kerja akan semakin meningkat seiring dengan meningkatnya industrialisasi dan teknologi. Kondisi demikian tentunya menuntut perusahaan agar perlindungan tenaga kerja dapat semakin mantap ditinjau dari produktifitas, kesehatan kerja dan keselamatan kerja dalam bekerja yang dapat berpengaruh pada produktifitas kerja. Untuk mencapai produktifitas yang tinggi tidaklah mudah karena perusahaan juga menghadapi kendala antara lain berhubungan dengan sumber daya manusia. Manusia adalah faktor yang penting dalam proses produksi karena sumber daya manusia merupakan asset yang penting dalam suatu perusahaan. Suatu proses produksi yang tidak lancar kerena kecelakaan kerja akan mengakibatkan berkurangnya efisiensi. Penurunan produktifitas dapat terjadi karena mesin yang rusak, karyawan yang cidera dan sebagainya. Produktifitas akan optimal bila tenaga kerja selalu terjamin keselamatan dan kesehatan kerja.

Jika perusahaan dapat menurunkan tingkat dan beratnya kecelakaan kerja, penyakit dan hal - hal yang berkaitan dengan stress, serta mampu meningkatkan kualitas kehidupan kerja para pekerjanya, perusahaan akan semakin efektif. Peningkatan - peningkatan terhadap hal ini akan menghasilkan meningkatnya produktifitas karena menurunnya hari kerja yang hilang, meningkatnya efisiensi dan kualitas pekerja yang lebih berkomitmen, menurunnya biaya - biaya kesehatan dan asuransi, tingkat 
kompensasi pekerja dan pembayaran langsung yang lebih rendah karena menurunnya pengajuan klaim, fleksibilitas dan adaptabilitas yang besar sebagai akibat dari meningkatnya partisipasi dan rasa kepemilikan dan rasio seleksi tenaga kerja yang lebih baik karena meningkatnya citra perusahaan (Kusuma, 2009: 8).

Kecelakaan industri secara umum disebabkan oleh 2 hal pokok yaitu perilaku kerja yang berbahaya (unsafe human act) dan kondisi yang berbahaya (unsafe condistions). Beberapa hasil penelitian menunjukkkan bahwa faktor manusia memegang pernanan penting timbulnya kecelakaan kerja. Hasil penelitian menyatakan bahwa 80\%-85\% kecelkaan keja disebebkan oleh kelalaian atau kesalahan faktor manusia.

PT. Sarana Bandar Nasional merupakan anak perusahaan PT. PELNI ( Persero) salah satu perusahaan pelayaran terkemuka di Indonesia. PT.Sarana Bandar Nasional kini bermertafosa branding menjadi Pelni Logistics. Berdiri sejak 31 Maret 1986 Pelni Logistics menangani bisnis jasa bongkar muat barang dari kapal induk perusahaan maupun kapal-kapal lainnya. Freight Forwarding, pergudangan, transportasi dan penimbunan sementara. Wilayah usaha Pelni logistics meliputi seluruh Nusantara dengan didukung 56 cabang dan sub cabang yang beroperasi di pelabuhan besar dan pelabuhan kecil yang tersebar dari Sabang sampai Merauke dengan kantor pusat di Jakarta. Tetapi pada PT. Sarana Bandar Nasional mengalami permasalahan dengan tingginya data pekerjaan tidak tepat waktu yang jelas mengganggu tujuan perusahaan. Data perusahaan menunjukkan bahwa selama tahun 2013 hingga tahun 2015 jumlah pekerjaan tepat waktu terus meningkat, namun jumlah pekerjaan tidak tepat waktu tersebut juga meningkat. Kondisi pekerjaan tidak tepat waktu ini mengakibatkan ketidaksesuaian antara target jumlah pekerjaan yang seharusnya tercapai dikerjakan per tahun dengan realisasi pekerjaan selesai tepat waktu pada PT. Sarana Bandar Nasional.

Meningkatnya jumlah pekerjaan yang tidak tepat waktu di indikasikan masih banyaknya karyawan yang masih belum menerapkan aturan dan prosedur dalam bekerja, sehingga sering terjadi kecelakaan kerja. Perusahaan dapat menggunakan faktor kesehatan dan keselamatan sebagai motivator bagi karyawannya sehingga kinerja perusahaan meningkat, dan karyawan pun dapat memperoleh kesejahteraan.

Dengan demikian Kesehatan dan Keselamatan kerja tidak dipandang sebagai suatu syarat dan aturan yang memberatkan perusahaan, tetapi justru sangat bermanfaat bagi perusahaan. Dengan tingkat kesehatan dan keselamatan kerja yang baik jelas mangkir kerja karena sakit akan menurun, biaya pengobatan dan perawatan akan menurun, kerugian akibat kecelakaan akan berkurang, tenaga kerja akan mampu bekerja dengan lebih tinggi, keuntungan akan meningkat dan tentunya kesejahteraan karyawan akan meningkat sehingga dapat meningkatkan motivasi dan meningkatkan kinerja karyawan pada perusahaan tersebut.

Jumlah kecelakaan kerja pada tahun 2013 sampai dengan tahun 2015 mengalami peningkatan. Meningkatnya kecelakaan kerja di perusahaan menjadi perhatian yang lebih bagi perusahaan, salah satunya adalah dengan pemberian Kesehatan dan Keselamatan Kerja (K3) kepada para karyawan. selain bertujuan untuk menghindari kecelakaan dalam proses produksi perusahaan, Kesehatan dan Keselamatan Kerja (K3) juga bertujuan untuk meningkatkan kegairahan, keserasaian kerja dan partisipasi kerja karyawan dan dapat dipastikan kinerja dari karyawan meningkat. Ketika karyawan merasa terjamin keselamatan dan kesehatan kerja diharapkan karyawan termotivasi bekerja seoptimal mungkin.

Jumlah kecelakaan kerja pada tahun 2013 sampai dengan tahun 2015 mengalami peningkatan. Meningkatnya kecelakaan kerja di perusahaan menjadi perhatian yang lebih bagi perusahaan, salah satunya adalah dengan pemberian Kesehatan dan Keselamatan Kerja (K3) kepada para karyawan. selain bertujuan untuk menghindari kecelakaan dalam proses produksi perusahaan, Kesehatan dan Keselamatan Kerja (K3) juga bertujuan untuk meningkatkan kegairahan, keserasaian kerja dan partisipasi kerja karyawan dan dapat dipastikan kinerja dari karyawan meningkat. Ketika karyawan merasa terjamin keselamatan dan kesehatan kerja diharapkan karyawan termotivasi bekerja seoptimal mungkin.

Berdasarkan uraian diatas, maka perumusan masalah dalam penelitian ini adalah sebagai berikut:

1. Apakah variabel Kesehatan \& Keselamatan Kerja berkorelasi secara signifikan dengan kinerja karyawan ?

2. Apakah variabel Motivasi berkorelasi secara signifikan dengan kinerja karyawan ?

\section{Tinjauan Pustaka}

\subsection{Keselamatan dan Kesehatan Kerja}

Kesehatan dan keselamatan kerja (K3) dapat juga diartikan sebagai suatu sistem yang dibuat bagi tenaga kerja maupun pengusaha sebagai upaya pencegahan (preventif) timbulnya kecelakaan dan penyakit kerja akibat hubungan kerja dalam lingkungan kerja dengan cara mengenali hal-hal yang berpotensi menimbulkan kecelakaan dan penyakit kerja akibat hubungan kerja, dan tindakan antisipatif bila terjadi hal demikian. (Dewi Kurniawati, 2013 : 1). Kesehatan dan keselamatan kerja (K3) pada dasarnya mencari dan mengungkapkan kelemahan yang memungkinkan terjadinya kecelakaan. Fungsi ini dapat dilakukan dengan dua cara, yaitu mengungkapkan sebab-akibat suatu kecelakaan dan meneliti apakah pengendalian secara cermat dilakukan atau tidak. Kesehatan dan keselamatan kerja (K3) menjadi salah satu prioritas yang utama bagi perusahaan untuk melindungi pekerja dari bahaya yang menimpa. Tenaga kerja yang sehat merupakan faktor penentu yang vital 
bagi pertumbuhan suatu perusahaan. Produktifitas tenaga kerja akan menurun apabila tenaga kerja tersebut terganggu kesehatannya (Dewi kurniawati, $2013: 3$ ).

Keselamatan kerja menunjukkan kondisi yang aman atau selamat dari penderitaan, kerusakan atau kerugian di tempat kerja. Risiko keselamatan merupakan aspek-aspek dari lingkungan kerja yang dapat menyebabkan kebakaran, ketakutan aliran listrik, terpotong, luka memar, keseleo, patah tulang, kerugian alat tubuh, penglihatan, san pendengaran. Semua itu sering dihubungkan dengan perlengkapan perusahaan atau lingkungan fisik dan mencakup tugas-tugas kerja yang membutuhkan pemeliharaan dan latihan. (Sungkono, 2014 : 69) Keselamatan kerja menurut Mondy dalam Tsenawatme (2013:2) adalah perlindungan karyawan dari luka-luka yang disebabkan oleh kecelakaan yang terkait dengan pekerjaan.

Sedangkan kesehatan kerja menunjukkan pada kondisi yang bebas dari kondisi yang bebas dari kondisi yang bebas dari fisik, mental, emosi atau rasa sakit yang disebabkan oleh lingkungan kerja. Kesehatan kerja menunjukkan pada kondisi yang bebas dari gangguan fisik, mental, emosi atau rasa sakit yang disebabkan oleh lingkungan kerja. Risiko kesehatan merupakan faktor-faktor dalam lingkungan kerja yang bekerja melebihi periode waktu yang ditentukan, lingkungan yang dapat membuat stres, emosi atau gangguan fisik. (Sungkono, $2014: 69)$

Keselamatan dan kesehatan Kerja (K3) merupakan salah satu cara untuk melindungi para karyawan dari bahaya kecelakaan kerja dan penyakit akibat kerja selama bekerja. Terkadang pelaksanaan keselamatan dan kesehatan Kerja (K3) tidak diperhatikan dalam kinerja karyawan sehingga akan mengganggu produktivitas kerja karyawan, jika keselamatan dan kesehatan Kerja (K3) diterapkan dan dilaksanakan maka akan tumbuh hasil kinerja yang memuaskan karena karyawan merasa di perhatikan oleh Perusahaan mengenai keselamatan dan kesehatannya. Kesehatan para karyawan bisa terganggu karena penyakit akibat kerja, maupun karena keselamatan kerja yang tidak diperhatikan.

Menurut Rivai dalam Munandar (2014 : 2) keselamatan dan kesehatan kerja merujuk kepada kondisikondisi fisiologis-fiskal dan psikologis tenaga kerja yang diakibatkan oleh lingkungan kerja yang disediakan oleh perusahaan. Jika sebuah perusahaan melakukan tindakan-tindakan keselamatan dankesehatan yang efektif, maka lebih sedikit pekerja yang menderita cidera atau penyakit jangka pendek maupun jangka panjang sebagai akibat dari pekerjaan mereka di perusahaan tersebut.

Kesehatan dan Keselamatan Kerja (K3) adalah upaya nyata untuk menjamin kelestarian tenaga kerja pada khususnya dan setiap insane pada umumnya. (Ardana, 2011: 208)

\subsection{Motivasi Kerja}

Motivasi merupakan salah satu hal yang penting dalam kerangka pengembangan sumber daya manusia karena hal ini berkaitan erat dengan pemimpin dan yang dipimpin. Prestasi kerja sebagai hasil dari interaksi antar pemimpin dengan yang dipimpin. Suatu organisasi atau perusahaan didirikan untuk mencapai tujuan yang telah ditetapkan sebelumnya. Tujuan tersebut berupa tujuan jangka panjang, menengah dan tujuan jangka pendek. Motivasi adalah segala sesuatu yang menimbulkan dorongan atau semangat kerja atau pendorong semangat kerja (Ardana, 2011: 193)

Motivasi adalah daya penggerak di dalam diri seseorang untuk berbuat sesuatu. Motivasi merupakan keadaan internal organisme (individu), yang mendorongnya untuk berbuat sesuatu. Motivasi berperan sebagai pemasok daya (energizer) untuk bertingkah laku secara terarah. Motivasi sering pula dimaknakan sebagai modal dasar, yang fungsinya mendorong seorang untuk beraktivitas, bahkan mampu melipatgandakan potensi dirinya. Teori-teori tentang motivasi banyak dipelajari dalam ranah studi psikologi dan manajemen. Teori ini berkaitan dengan perilaku individu, dan kedua ranah studi tersebut memang berkaitan dengan perilaku individu. Salah satu tokoh yang cukup dikenal adalah Abraham Maslow. Beliau adalah pionir dari aliran psikologi humanistik. Teorinya yang cukup terkenal adalah mengenai Theory of Hierarchy Needs. Menurutnya, manusia memunculkan suatu perilaku didasarkan pada kebutuhan yang ada.

Maslow berargumen bahwa seseorang tidak akan mencapai tingkat kebutuhan yang lebih tinggi sebelum tercapai kebutuhan yang di bawahnya. Misalnya, seseorang akan sulit mendapatkan kebutuhan akan cinta kalau kebutuhan fisiologisnya belum tercapai. Begitu seterusnya hingga sampai kebutuhan aktualisasi diri. Namun dalam penelitian selanjutnya ternyata ada individu yang tidak begitu saja harus membutuhkan kebutuhan di bawahnya sebelum meraih kebutuhan yang di atasnya. Penelitian mengenai peak-experience terhadap orangorang yang memiliki pengalaman spiritual seperti Mahatma Gandhi, Bunda Theresa, yang kemudian mengoreksi teori tersebut. Orang-orang semacam Gandhi atau Theresa yang langsung mencapai tingkat aktulalisasi diri tanpa melalui strata kebutuhan yang di bawahnya.

Sedangkan Wahjosumidjo dalam Munandar (2014 : 3) mengatakan bahwa "motivasi merupakan suatu proses psikologis yang mencerminkan interaksi antara sikap, kebutuhan, persepsi dan keputusan yang terjadi pada diri seseorang." Motivasi sebagai proses psikologis yang timbul diakibatkan oleh faktor di dalam diri seseorang itu sendiri yang disebut intrinsik atau faktor dari luar yang disebut ekstrinsik. Faktor dari dalam diri seseorang dapat berupa kepribadian, sikap, pengalaman dan pendidikan, atau berbagai harapan, cita-cita yang menjangkau ke masa depan, bisa karena pengaruh pimpinan, kolega atau faktor-faktor lain. Sedangkan faktor 
diluar diri dapat ditimbulkan oleh berbagai sumber bisa karena pengaruh pimpinan, kolega atau faktor-faktor lain yang sangat kompleks.

Berdasarkan pendapat di atas, dapat disimpulkan bahwa motif merupakan suatu dorongan kebutuhan dalam diri karyawan yang perlu dipenuhi agar karyawan tersebut dapat menyesuaikan diri terhadap lingkungannya, sedangkan motivasi adalah suatu proses yang menghasilkan suatu intensitas arah (tujuan) dan ketekunan individual dalam perilakunya.

\subsection{Kinerja Karyawan}

Kinerja merupakan perwujudan kerja yang dilakukan oleh karyawan atau organisasi. Kinerja yang baik merupakan langkah untuk tercapainya tujuan organisasi sehingga perlu diupayakan untuk meningkatkan kinerja.Tetapi hal ini tidak mudah dilakukan sebab banyak faktor yang mempengaruhi tingkat tinggi rendahnya kinerja seseorang.

Setiap manusia mempunyai potensi untuk bertindak dalam berbagai bentuk aktivitas. Kemampuan bertindak itu dapat diperoleh manusia baik secara alami (ada sejak lahir) atau dipelajari. Walaupun manusia mempunyai potensi untuk berperilaku tertentu tetapi perilaku itu hanya diaktualisasi pada saat-saat tertentu saja. Potensi untuk berperilaku tertentu itu disebut ability (kemampuan), sedangkan ekspresi dari potensi ini dikenal sebagai performance (kinerja).

Menurut Rivai dan Basri dalam Kaswan (2012: 187) lebih spesifik mengatakan bahwa, "Kinerja adalah hasil atau tingkat keberhasilan seseorang secara keseluruhan selama periode tertentu didalam melaksanakan tugas dibandingkan dengan berbagai kemungkinan, seperti standar hasil kerja, target atau sasaran, atau kriteria yang telah ditentukan terlebih dahulu dan telah disepakati bersama."

Sedangkan menurut Wibowo (2012: 81) lebih spesifik mengatakan bahwa, "Kinerja merupakan proses tentang bagaimana pekerjaan berlangsung untuk mencapai hasil kerja."

Dari definisi diatas, maka dapat ditarik kesimpulan bahwa kinerja adalah proses atau hasil pekerjaan yang mempengaruhi seberapa banyak seorang karyawan memberikan kontribusi kepada organisasi.

\subsection{Teori Hubungan Keselamatan dan Kesehatan Kerja terhadap Kinerja Karyawan}

Perusahaan yang baik adalah perusahaan yang benar-benar menjaga keselamatan karyawannya dengan membuat aturan tentang keselamatan dan kesehatan kerja yang dilaksanakan oleh seluruh karyawan dan pimpinan perusahaan. Perlindungan tenaga kerja dari bahaya dan penyakit akibat kerja atau akibat dari lingkungan kerja sangat dibutuhkan oleh karyawan agar karyawan merasa aman dan nyaman dalam menyelesaikan pekerjaannya. Tenaga kerja yang sehat akan bekerja produktif, sehingga diharapkan kinerja karyawan meningkat yang dapat mendukung keberhasilan bisnis perusahaan dalam membesarkan usahanya. (Trisyulianti, 2010:1)

Perhatian lebih yang diberikan oleh perusahaan salah satunya adalah dengan pemberian Kesehatan dan Keselamatan Kerja (K3) kepada para karyawan. Menurut Notoatmodjo (2009:153) tujuan utama Kesehatan dan Keselamatan Kerja (K3) adalah agar karyawan atau pegawai di sebuah institusi mendapat kesehatan yang seoptimal mungkin sehingga mencapai Produktivitas Kerja yang setinggi-tingginya. Menurut Mangkunegara (2004:162), selain bertujuan untuk menghindari kecelakaan dalam proses produksi perusahaan, Kesehatan dan Keselamatan Kerja (K3) juga bertujuan untuk meningkatkan kegairahan, keserasaian kerja dan partisipasi kerja karyawan dan dapat dipastikan kinerja dari karyawan meningkat.

Perusahaan perlu melaksanakan program Kesehatan dan Keselamatan Kerja (K-3) yang diharapkan dapat menurunkan tingkat kecelakaan kerja, dan pada akhirnya akan dapat meningkatkan kinerja perusahaan dan kinerja kerja karyawan. pelaksanaan program Kesehatan dan Keselamatan Kerja perlu dan sangat penting, karena membantu terwujudnya pemeliharaan karyawan yang baik, sehingga mereka menyadari arti penting dari pelaksanaan program keselamatan dan kesehatan kerja bagi dirinya maupun perusahaan. (Husni, 2009: 2). Hasil penelitian Husni (2009) menunjukkan bahwa program K3 signifikan terhadap kinerja karyawan. Jadi dapat disimpulkan bahwa Keselamatan Kerja berpengaruh positif terhadap kinerja karyawan. Dengan adanya jaminan atau program Keselamatan Kerja yang diberikan oleh perusahaan maka diharapkan kinerja dari karyawan dapat berjalan sesuai yang diinginkan perusahaan.

\subsection{Hubungan Motivasi terhadap Kinerja Karyawan}

Teori motivasi merupakan suatu pandangan yang dapat digunakan sebagai acuan untuk memberikan motivasi kepada orang-orang atau kelompok tertentu dalam suatu unit bisnis. Motivasi dapat menyebabkan seseorang untuk berperilaku baik, oleh karena itu motivasi karyawan yang tinggi berbanding lurus dengan kinerja perusahaan.

Seorang karyawan yang termotivasi akan berisifat energik dan bersemangat dalam mengerjakan tugastugas yang diberikan kepadanya. Sebaliknya para karyawan yang memiliki motivasi yang rendah akan sering menampilkan rasa tidak nyaman dan tidak senang terhadap pekerjaannya. Akibatnya kinerja mereka menjadi buruk dan tujuan perusahaan tidak akan tercapai. Marjani (2005) mengemukakan bahwa ada hubungan positif 
antara motivasi dengan kinerja pegawai. Dalam penelitian tersebut ditemukan hasil bahwa tingginya kondisi motivasi kerja pegawai berhubungan dengan kecenderungan pencapaian tingkat kinerja pegawai yang cukup tinggi. Pegawai yang memiliki motivasi yang tinggi, mereka akan berupaya untuk melakukan semaksimal mungkin tujuan yang ditetapkan oleh perusahaan (Murty $2012: 219$ )

\subsection{Hipotesis} berikut :

Berdasarkan pokok permasalahan dan tujuan penelitian, maka hipotesis yang diajukan adalah sebagai

a. Kesehatan dan Keselamatan kerja mempunyai hubungan yang sangat erat dengan kinerja karyawan

b. Motivasi mempunyai hubungan yang sangat erat dengan kinerja

\section{Metodologi Penelitian}

Penelitian ini menggunakan pendekatan kuantitatif yaitu penelitin yang menitik beratkan pada pengujian hipotesis. Data yang digunakan harus terukur dan akan mengasilkan suatu simpulan yang dapat digeneralisasikan.

Jenis penelitian ini adalah explanatory research (penelitian penjelasan). Menurut Menurut Singarimbun dan Efendy (1995), penelitian penjelasan merupakan penelitian yang menyoroti hubungan variabel-variabel penelitian dan menguji hipotesa yang telah dirumuskan sebelumnya. Oleh karena itu, penelitian ini juga dinamakan pengujian hipotesa atau testing research.

Adapun dasar utama pemilihan ini adalah untuk menguji hipotesa yang telah digunakan sebelumnya . melalui uji hipotesis tersebut diharapkan dapat menjelaskan pengaruh K3 dan Motivasi terhadap Kinerja

\subsection{Populasi dan Sampel \\ 3.1.1 Populasi}

Merupakan wilayah generalisasi yang terdiri atas obyek / subyek yang mempunyai kuantitas dan karakteristik tertentu yang ditetapkan oleh peneliti untuk dipelajari dan kemudian ditarik kesimpulan, menurut (Sugiyono 2015: 57). Populasi yang dipergunakan dalam penelitian ini adalah karyawan PT. Sarana Bandar Nasional Surabaya yang berjumlah 40 orang.

\subsubsection{Sampel}

Sampel adalah bagian dari sebuah populasi, yang mempunyai ciri dan karakteristik yang sama dengan populasi tersebut, karena itu sebuah sampel harus merupakan representatif dari sebuah populasi, (Sugiyono, 2010:117). Dalam melakukan penarikan sampel, digunakan metode Sampling jenuh yaitu teknik penentuan sampel bila anggota populasi digunakan sebagai sampel. Istilah lain sampling jenuh adalah sensus, dimana semua anggota populasi dijadikan sebagai sampel. Maka sampel yang diambil adalah sebanyak 40 responden

\subsection{Variabel dan Definisi Operasional}

Agar suatu variabel yang akan digunakan dapat diukur serta menghilangkan dan menghindari adanya kesalahan dalam penaksiran makna, perlu adanya definisi sebagai berikut :

1) Kesehatan dan Keselamatan Kerja $\left(X_{1}\right)$

Keselamatan kerja adalah keadaan karyawan yang bebas dari rasa takut dan bebas dari segala kemungkinan resiko kerja. (Pertiwi, $2013: 6$ )

2) Motivasi (X2)

Motivasi merupakan kesediaan dari seorang karyawan dalam usahanya untuk melakukan kegiatan dengan baik dengan maksud agar tujuan perusahaan dapat tercapai. (Yoesana, $2013: 22$ )

3) Kinerja dalam penelitian ini berpedoman kepada jumlah yang dihasilkan atauupaya untuk menghasilkan keluaran berdasarkan standar yang ditetapkan. (Pertiwi : 2013 : 7)

\subsection{Teknik Analisis Data}

Metode analisa ini digunakan untuk menganalisis ada tidaknya hubungan antara variabel, jika ada hubungan maka berapa besar pengaruhnya. Menurut Sugiyono (2011:282) "korelasi spearman rank digunakan mencari atau untuk menguji signifikansi hipotesis asosiatif bila masing-masing variabel yang dihubungkan berbentuk ordinal, dan sumber data antar variabel tidak harus sama". Selanjutnya untuk mengetahui keeretan atau derajat hubungan variabel $\mathrm{X}$ dengan variabel $\mathrm{Y}$, dapat diukur dengan menggunakan rumus Spearman melalui langkah - langkah sebagai berikut:

$$
r_{s}=1-\frac{6 \sum d i^{2}}{n\left(n^{2}-1\right)}
$$


Dimana :

$r_{s}=$ koefisien korelasi Spearman $\quad \Sigma=$ notasi jumlah

$d_{i}=$ perbedaan rangking antara pasangan data $\mathrm{n}=$ banyaknya pasangan data

Besarnya koefisien Korelasi Spearman $\left(r_{s}\right)$ bervariasi yang memiliki batasan batasan antara $-1<r<1$, interprestasikan dan nilai koefisien korelasinya adalah :

jika nilai $r>0$, artinya telah terjadi hubungan yang linier positif, yaitu makin besar nilai variabel $X$ (independent) maka besar pula nilai variabel Y (dependent), atau makin kecil nilai variabel $\mathrm{X}$ (independent) maka makin kecil pula nilai variabel Y (dependent).

jika nilai $\mathrm{r}<0$, artinya telah terjadi hubungan yang linier negatif, yaitu makin kecil nilai variabel $\mathrm{X}$ (independent) maka makin besar nilai variabel Y (dependent), atau makin besar nilai variabel X (independent) maka makin kecil pula nilai variabel Y (dependent).

Jika nilai $\mathrm{r}=0$, artinya tidak ada hubungan sama sekali antara variabel $\mathrm{X}$ (independent) dengan variabel $\mathrm{Y}($ dependent).

Jika nilai $r=1$ atau $r=-1$, artinya telah terjadi hubungan linier sempurna berupa garis lurus, sedangkan untuk nilai $r$ yang makin mengarah ke angka 0 maka garis makin tidak lurus.

Namun untuk dapat memudahkan pengolahan korelasimya penulis menggunakan software SPSS 20. Untuk dapat memberikan penafsiran terhadap koefisien korelasi yang ditemukan tersebut besar atau kecil pengaruhnya, maka dapat berpedoman pada ketentuan yang tertera pada tabel sebagai berikut :

\begin{tabular}{cc}
\multicolumn{2}{c}{ Tabel 1.Pedoman Interpretasi Koefisien Korelasi } \\
\hline Interval Koefisien & Tingkat Hubungan \\
\hline $0,00-0,199$ & Sangat Rendah \\
$0,20-0,399$ & Rendah \\
$0,40-0,599$ & Sedang \\
$0,60-0,799$ & Kuat \\
$0,80-1,000$ & Sangat Kuat \\
\hline \multicolumn{2}{c}{ Sumber : Sugiyono $(2010: 183)$}
\end{tabular}

\section{Hasil Penelitian Dan Pembahasan}

\subsection{Analisa Data dan Pengujian Hipotesis}

\subsubsection{Pembahasan Hasil Penelitian}

Variabel yang diteliti dalam penelitian ini adalah hubungan antara lingkungan kerja, kompensasi dan beban kerja dengan kinerja karyawan.

Cara melaksanakan analisis terhadap data, dengan tujuan mengolah data tersebut menjadi informasi, sehingga karakteristik atau sifat-sifat datanya dapat dengan mudah dipahami dan bermanfaat untuk menjawab masalah-masalah yang berkaitan dengan kegiatan penelitian, baik berkaitan dengan deskripsi data maupun untuk membuat induksi, atau menarik kesimpulan tentang karakteristik populasi (parameter) berdasarkan data yang diperoleh dari sampel (statistik).

Teknik analisis data yang digunakan dalam penelitian ini adalah dengan uji korelasi Rank Spearman karena data yang diperoleh adalah berupa data ordinal yang diperoleh dari angket dengan jenis skala Likert,) Skala Likert merupakan jenis skala pengukuran yang menyediakan data berbentuk ordinal." Uji koefisien korelasi ini dimaksudkan untuk menguji hubungan dari dua variabel yang diteliti, untuk mengetahui derajat hubungan antara variabel $\mathrm{X}$ dan variabel $\mathrm{Y}$.

Setelah tahap pengujian kualitas data yaitu menguji validitas dan reliabilitas instrumen pengumpul data dilakukan selanjutnya pelaksanaan penelitian (pengambilan data) setelah data didapat dan ditabulasi selanjutnya dilakukan pengujuan hipotesis. Pengujian hipotesis dilakukan agar dapat diketahui kesesuaian antara hipotesis yang telah dirumuskan dengan hasil data yang didapat dari penelitian. Untuk menguji hipotesis ini digunakan uji non parametrik dengan menggunakan rumus Rank Spearman dengan bantuan program perhitungan SPSS (Statistical Product and Service Solution) versi 20.0.

Untuk dapat mengetahui kuat lemahnya tingkat atau derajat keeratan hubungan antara variabel-variabel yang diteliti, digunakan tabel kriteria pedoman untuk koefisien korelasi sesuai dengan pendapat Sugiyono (2010:257). Uji signifikansi dapat diperoleh dengan cara:

Jika taraf siginifikansi $<\alpha$, maka terdapat hubungan.

Jika taraf siginifikansi $>\alpha$, maka tidak terdapat hubungan.

\subsubsection{Korelasi antara Kesehatan dan Keselamatan Kerja Terhadap Kinerja Karyawan}


Tabel 2. Uji Hipotesis Korelasi X1 dan Y Correlations

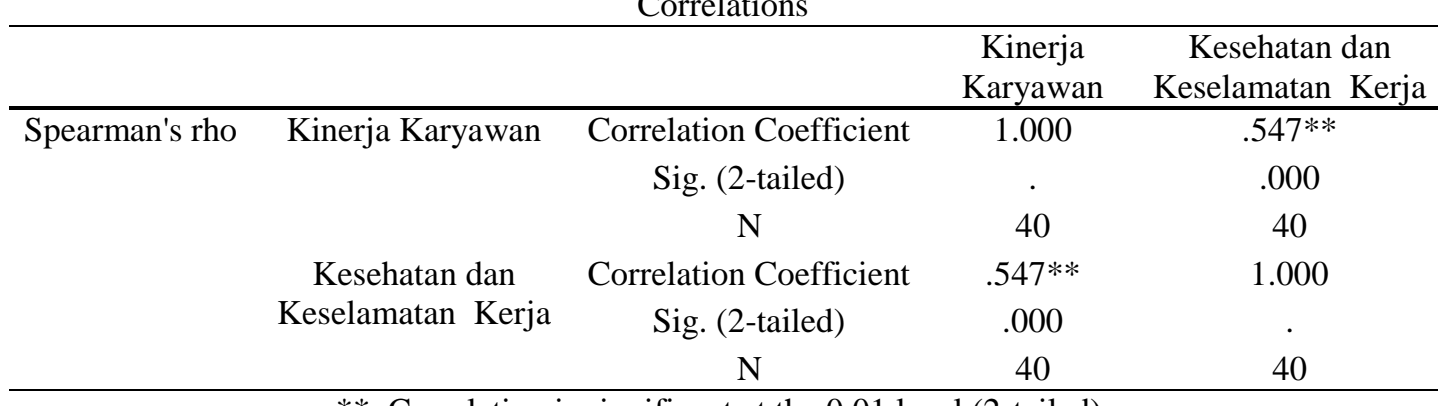

**. Correlation is significant at the 0.01 level (2-tailed).

*. Correlation is significant at the 0.05 level (2-tailed).

Berdasarkan perhitungan diatas diperoleh nilai koefisiensi korelasi Keselamatan dan Kesehatan Kerja sebesar 0.547 dengan taraf signifikansi sebesar 0.000 pada tingkat taraf kepercayaan 0.05 atau $95 \%$ adapun tingkat kriteria pengujian:

Jika taraf signifikansi $<\alpha$, maka terdapat hubungan

Jika taraf signifikansi $>\alpha$, maka tidak terdapat hubungan

Dari hasil perhitungan diperoleh nilai signifikansi sebesar $0.000<\alpha(0.05)$ maka hipotesis diterima. Artinya terdapat hubungan yang signifikan antara keselamatan dan kesehatan kerja dengan kinerja karyawan. Hubungan ini ditunjukan dengan nilai korelasi sebesar 0.547 yang termasuk kedalam kategori sedang (0.400.599).

\subsubsection{Korelasi antara Motivasi Terhadap Kinerja Karyawan}

\begin{tabular}{ccccc}
\multicolumn{5}{c}{$\begin{array}{c}\text { Tabel 3. Uji Hipotesis Korelasi X2 dan Y } \\
\text { Correlations }\end{array}$} \\
\hline Spearman's rho & Kinerja Karyawan & Correlation Coefficient & 1.000 & $.703^{* *}$ \\
& & Sig. (2-tailed) &. & .000 \\
& Motivasi & $\mathrm{N}$ & 40 & 40 \\
& & Correlation Coefficient & $.703 * *$ & 1.000 \\
& Sig. (2-tailed) & .000 &. \\
& & $\mathrm{~N}$ & 40 & 40 \\
\hline
\end{tabular}

**. Correlation is significant at the 0.01 level (2-tailed).

*. Correlation is significant at the 0.05 level (2-tailed).

Berdasarkan perhitungan diatas diperoleh nilai koefisiensi korelasi motivasi sebesar 0.703 dengan taraf signifikansi sebesar 0.000 pada tingkat taraf kepercayaan 0.05 atau $95 \%$ adapun tingkat kriteria pengujian:

1. Jika taraf signifikansi $<\alpha$, maka terdapat hubungan

2. Jika taraf signifikansi $>\alpha$, maka tidak terdapat hubungan

Dari hasil perhitungan diperoleh nilai signifikansi sebesar $0.000<\alpha(0.05)$ maka hipotesis diterima. Artinya terdapat hubungan yang signifikan antara motivasi dengan kinerja karyawan. Hubungan ini ditunjukan dengan nilai korelasi sebesar 0.703 yang termasuk kedalam kategori kuat $(0,60-0,799)$.

\subsection{Pembahasan Uji Hipotesis 1}

Berdasarkan hasil pengujian diatas, diperoleh hasil Kesehatan dan Keselamatan Kerja signifikan terhadap kinerja karyawan dan memiliki hubungan yang sedang terhadap Kinerja Karyawan. Hubungan ini ditunjukan dengan nilai korelasi sebesar 0.547 yang termasuk kedalam kategori sedang (0.40-0.599). Hal ini menunjukkan bahwa dengan adanya keselamatan dan kesehatan kerja yang memadai di PT. Sarana Bandar Nasional akan meningkatkan kinerja karyawan. Kelengkapan dan pemakaian Alat Pelindung Diri merupakan salah satu elemen yang patut diperhatikan oleh PT. Sarana Bandar Nasional agar dapat memperkecil risiko terkena kecelakaan kerja dan/ atau penyakit kerja. Perusahaan telah mengantisipasi hal itu dengan menyediakan kelengkapan alat pelindung diri. Alat pelindung diri yang disediakan oleh perusahaan adalah berupa sarung tangan, masker, topi, dan sepatu untuk karyawan laki-laki. Selain itu, topi untuk karyawan laki-laki dan wanita pun juga mempunyai bentuk yang berbeda. Alat pelindung diri dari perusahaan tersebut dapat membuat sebagian besar karyawan yang menjadi responden merasa lebih aman dan nyaman dalam bekerja. Hal ini berarti 
sesuai dengan teori (Trisyulianti, 2010:1) yang menyatakan bahwa perusahaan yang baik adalah perusahaan yang benar-benar menjaga keselamatan karyawannya dengan membuat aturan tentang keselamatan dan kesehatan kerja yang dilaksanakan oleh seluruh karyawan dan pimpinan perusahaan. Perlindungan tenaga kerja dari bahaya dan penyakit akibat kerja atau akibat dari lingkungan kerja sangat dibutuhkan oleh karyawan agar karyawan merasa aman dan nyaman dalam menyelesaikan pekerjaannya. Tenaga kerja yang sehat akan bekerja produktif, sehingga diharapkan kinerja karyawan meningkat yang dapat mendukung keberhasilan bisnis perusahaan dalam membesarkan usahanya.

Hal ini menunjukkan bahwa semakin baik program kesehatan kerja yang diberika perusahaan, maka kinerja karyawan akan semakin meningkat. Faktor tersedianya fasilitas dan tempat karyawan untuk berobat menjadi factor terbesar yang mempengaruhi kesehatan, misalnya kotak P3K yang bisa digunakan jika sewaktu - waktu terjadi kecelakaan saat di lingkungan kerja. Hal ini berarti sesuai dengan teori Mangkunegara (2000:162), selain bertujuan untuk menghindari kecelakaan dalam proses produksi perusahaan, Kesehatan dan Keselamatan Kerja juga bertujuan untuk meningkatkan kegairahan, keserasian kerja dan partisipasi kerja karyawan. Kesehatan Kerja karyawan merupakan tanggung jawab perusahaan, dimana hal tersebut dapat membawa dampak atau Hubungan secara langsung kepada para karyawan dalam bekerja. Pemberian fasilitasfasilitas pendukung dan peraturan-peraturan sangat diperlukan dalam mewujudkan usaha-usaha meningkatkan Kesehatan Kerja.

\subsection{Pembahasan Uji Hipotesis 2}

Berdasarkan hasil pengujian diatas, Motivasi signifikan terhadap kinerja karyawan, dan memiliki hubungan yang kuat terhadap Kinerja karyawan. Hubungan ini ditunjukan dengan nilai korelasi sebesar 0.703 yang termasuk kedalam kategori kuat $(0,60-0,799)$. Hal ini menunjukkan bahwa karyawan pada PT. Sarana Bandar Nasional dalam bekerja mempunyai motivasi kerja yang cukup tinggi, hal ini ditunjukkan dari besarnya kemauan dan kemampuan karyawan dalam menyelesaikan suatu pekerjaan. Semakin tinggi motivasi kerja, maka semakin tinggi pula kinerja karyawan. Hal ini berarti sesuai dengan teori Marjani (2005) mengemukakan bahwa ada hubungan positif antara motivasi dengan kinerja pegawai. Dalam penelitian tersebut ditemukan hasil bahwa tingginya kondisi motivasi kerja pegawai berhubungan dengan kecenderungan pencapaian tingkat kinerja pegawai yang cukup tinggi. Pegawai yang memiliki motivasi yang tinggi, mereka akan berupaya untuk melakukan semaksimal mungkin tujuan yang ditetapkan oleh perusahaan.

\section{Kesimpulan Dan Saran \\ 5.1. Kesimpulan}

Berdasarkan analisis data dan pembahasan hasil penelitian yang telah dikemukakan, dapat disimpulkan hal-hal untuk menjawab permasalahan sebagai berikut :

1. Kesehatan dan Keselamatan kerja mempunyai hubungan yang sedang dengan kinerja karyawan

2. Motivasi mempunyai hubungan yang kuat dengan kinerja karyawan

\subsection{Saran}

Sehubungan dengan permasalahan dari hasil analisa data yang telah disajikan dihasil penelitian, maka dapat dikemukakan beberapa saran yang bermanfaat, antara lain :

1. Pihak perusahaan sebaiknya dapat menjaga, mempertahankan dan meningkatkan pemberian reward atau penghargaan bagi karyawan yang berprestasi agar lebih memotivasi karyawan dalam meningkatkan kinerja.

2. Pihak perusahaan sebaiknya dapat lebih meningkatkan Keselamatan karyawan yang meliputi pemberian tanda, kenyamanan tempat kerja seperti ada ventilasi yang cukup dan ruang untuk istirahat, pemeriksaan sistem listrik, secara terus - menerus untuk menghindari turunnya listrik. Adapun pemberian tanda peringatan pada peralatan kerja, untuk menekan jumlah kecelakaan kerja karyawan.

3. Perusahaan hendaknya meningkatkan informasi dan sosialisasi mengenai urgensi program K3 serta manfaatnya bagi karyawan khususnya dalam melakukan pekerjaan mereka.

4. Karyawan kiranya senantiasa berperan aktif dalam mensukseskan program K3 yang dicanangkan perusahaan sehingga kepuasan kerja dapat dirasakan bersama

5. Sebagai pertimbangan untuk penelitian berikutnya, disarankan agar menggunakan variabel lain diluar penelitian ini yang diduga mempunyai hubungan dengan kinerja karyawan seperti motivasi, dan lain-lain.

\section{Daftar Pustaka}

Ardana, I Komang, 2011, Manajemen Sumber Daya Manusia, Penerbit Graha Ilmu Arikunto, Suharsimi. 2010. Manajemen Penelitian. Jakarta : PT Rineka Cipta 
Ghozali, Imam. 2011. Aplikasi Analisis Multivariate Dengan Program IBM. SPSS 19 (edisi kelima.) Semarang: Universitas Diponegoro

Kaswan. 2012. Manajemen Sumber Daya Manusia untuk Keunggulan Bersaing. Organisasi. Graha Ilmu, Yogyakarta

Kurniawati, Dewi., 2013. Keselamatan dan Kesehatan Kerja. PT Aksara. Sinergi Media: Cetakan Pertama: Surakarta.

Maesaroh, Siti, 2010, Pengaruh Motivasi Kerja Dan Keselamatan, Kesehatan, Keamanan Kerja (K3) Terhadap Kinerja Karyawan PT. Masscom Graphy Semarang

Mangkunegara, Anwar Prabu. 2009. Manajemen Sumber Daya Manusia Perusahaan. Jakarta: PT. Remaja Rosdakarya.

Moh Nazir, 2011. Metode Penelitian. Cetakan 6. Bogor: Penerbit Ghalia.

Mulyadi, 2013, Pengaruh Kesehatan Dan Keselamatan Kerja (K3) Terhadap Kinerja Karyawan PT. Emitraco Investama Mandiri Divisi Engineering

Munandar, 2014, Pengaruh Keselamatan, Kesehatan Kerja (K3) Dan Insentif Terhadap Motivasi Dan Kinerja Karyawan (Studi Pada Pekerja bagian Produksi PT. Sekawan Karyatama Mandiri Sidoarjo)

Nugroho, Beni Setyo, 2010, Kesehatan Dan Keselamatan Kerja Sebagai Salah Satu Faktor Motivasi Kerja

Paramita, Catarina Cori Pradnya, 2012, Pengaruh Keselamatan Dan Kesehatan Kerja Terhadap Prestasi Kerja Karyawan Pada PT. PLN (Persero) APJ Semarang

Pertiwi, Pusma, 2013, Pengaruh Kesehatan Dan Keselamatan Kerja (K3) Terhadap Kinerja Karyawan PT. Emitraco Investama Mandiri Divisi Engineering, Economicus Jurnal Ilmiah

Rivai, Veithzal. 2011. Manajemen Sumber Daya Manusia Untuk Perusahaan. Jakarta: Penerbit Raja Grafindo Persada.

Siagian, Sondang. 2010. Manajemen Sumber Daya Manusia. Jakarta: PT Bumi Aksara

Sugiyono. 2011. Metode Penelitian Administrasi, Cetakan Ketujuh, Alfabeta CV, Bandung

Sungkono, 2014, Analisis Implementasi Sistem Manajemen Keselamatan dan Kesehatan Kerja Pada PT PLN (Persero) APJ Karawang Jawa Barat, Jurnal ilmiah Solusi Vol. 1 No. 4 Desember 2014 - Februari 2015

Tsenawatme, Aleks, 2012, Pengaruh Keselamatan Dan Kesehatan Kerja Terhadap Kinerja Karyawan

Yoesana, Umy , 2013, Hubungan Antara Motivasi Kerja Dengan Disiplin Kerja Pegawai Di Kantor Kecamatan Muara Jawa Kabupaten Kutai Kartanegara, eJournal Pemerintahan Integratif

Wibowo.2012. Manajemen Kinerja. Jakarta: Rajawali Press.

Trisyulianti, Erlin dan T. Lestari, 2010, Hubungan Keselamatan dan Kesehatan (K3) dengan Produktivitas Kerja Karyawan (Studi Kasus: Bagian Pengolahan PTPN VIII Gunung Mas, Bogor), Fakultas Ekonomi dan Manajemen IPB 